\title{
O PCB e o golpe civil-militar de 1964: causas e consequências ${ }^{\mathrm{a}}$
}

\author{
The PCB and the civilian-military coup of 1964: \\ causes and consequences
}

\author{
El PCB y el golpe civil-militar de 1964: \\ causas y consecuencias
}

Anita Leocadia Prestes ${ }^{b}$

\begin{abstract}
Resumo: A derrota das esquerdas em 1964 revela que o caminho da revolução socialista passa pela construção do bloco histórico contra-hegemônico, que represente a unidade de amplas forças sociais e políticas em torno de um projeto revolucionário condizente com a realidade atual do País. Tal projeto deverá resultar das lutas dos trabalhadores por objetivos parciais que contribuam para a conquista do poder político, objetivo sem o qual o processo revolucionário ficaria inconcluso e sujeito a novas derrotas.
\end{abstract}

Palavras-chave: Golpe de 1964. Partido Comunista Brasileiro. Bloco histórico.

Abstract: The defeat of the left in 1964 reveals that the way of the socialist revolution passes by the construction of the counter-hegemonic historical block, representing the unity of ample social and political forces around a revolutionary project consistent with the present reality of the Country. Such project will have to result from the struggles of the workers for partial objectives that may contribute to the conquest of political power; without this goal, the revolutionary project would remain unconcluded and subject to new defeats.

Keywords: 1964 Coup. Brazilian Communist Party. Historical block.

\footnotetext{
${ }^{\text {a N}}$ Nota da Editora: Parte deste texto foi inicialmente divulgado no Polo Comunista Luiz Carlos Prestes $<$ http://www.cclcp.org/index.php/inicio-pclcp/formacao $>$ e na página do Partido Comunista Brasileiro $<\mathrm{http}: / /$ pcb.org.br/portal/index.php?option $=$ com_content\&view $=$ article\&id $>$, sob o título "Por que as esquerdas foram derrotadas em 1964?" Considerando a relevância do texto e a originalidade dos dados empíricos analisados, a Revista Estudos Ibero-Americanos aceitou a republicação em caráter extraordinário.

${ }^{\text {b }}$ Doutora em História Social pela UFF e professora do Programa de Pós-Graduação em História Comparada da UFRJ.<anitaprestes@superig.com.br>.
} 
Resumen: La derrota de las izquierdas en 1964 ha revelado que el camino de la revolución socialista debería pasar por la construcción de un bloque histórico contra hegemónico que represente la unidad de amplias fuerzas sociales y políticas alrededor de un proyecto revolucionario adecuado a la realidad de entonces del país. Tal proyecto será, entonces, resultado de las luchas de los trabajadores por objetivos parciales que contribuyan para la conquista del poder político, sin el cual, el proceso revolucionario quedaría inacabado y expuesto a nuevas derrotas.

Palabras clave: Golpe de 1964. Partido Comunista Brasileño. Bloque histórico.

Tornou-se um truísmo, a partir de 1/4/1964, a crítica ao Partido Comunista Brasileiro (PCB) por não ter resistido ao golpe civil-militar, assim como a acusação de que tal posicionamento seria decorrência de sua política pacifista, do despreparo para a resistência aos golpistas e de ilusões na burguesia e no "dispositivo militar"1 do presidente João Goulart.

O PCB era o mais importante partido de esquerda na época, contando com destacadas lideranças sindicais à frente do Comando Geral dos Trabalhadores (CGT) e de numerosos sindicatos, com inúmeros aliados tanto no movimento sindical urbano quanto rural, com a presença significativa de seus militantes na União Nacional dos Estudantes (UNE) e junto ao movimento estudantil universitário e secundarista. Da mesma forma, o PCB exercia influência em múltiplos setores do mundo social e político brasileiro, em particular, junto a personalidades e a agrupamentos com posições democráticas e nacionalistas, que se pronunciavam contra a ingerência imperialista no país e pela reforma agrária.

Diante disso, como explicar a vitória dos golpistas e a derrota das esquerdas? E quais seriam as consequências dessa derrota?

\section{Os antecedentes}

É necessário retroceder no tempo e verificar qual era a perspectiva política e organizacional do PCB. Após a prisão dos membros da direção nacional do PCB em 1940 e o esfacelamento da organização partidária, vários grupos tentaram sua reorganização. Afinal, a reconstrução do $\mathrm{PCB}$

\footnotetext{
1 "Dispositivo militar" - denominação atribuída à época aos setores militares que supostamente dariam sustentação ao governo João Goulart, impedindo sua deposição.
} 
teve sucesso com a iniciativa da Comissão Nacional de Organização Provisória (CNOP) de convocar a II Conferência Nacional do PCB - conhecida como Conferência da Mantiqueira, porque se realizou clandestinamente, em algum lugar do Vale do Paraíba, em agosto de 1943, reunindo 48 militantes (Prestes, 2001, cap. IX) ${ }^{2}$.

O exame das concepções político-ideológicas norteadoras da Conferência é essencial para o esclarecimento das condições em que se formou o novo grupo dirigente eleito nessa oportunidade e que assumiu a direção do PCB, tratando de reunificá-lo. Vale lembrar a importância que Antônio Gramsci atribuía à formação do grupo dirigente do Partido Comunista. O líder comunista e teórico marxista escrevia que "todos os problemas de organização são problemas políticos" (Gramsci, 2004, v. 2, p. 348) e, preocupado com a construção do PC italiano, afirmava: "É preciso criar no interior do Partido um núcleo (...) de companheiros que tenham o máximo de homogeneidade ideológica e, portanto, consigam imprimir à ação partidária um máximo de unidade de orientação" (Gramsci, 2004, v. 2, p. 129-130). Para Gramsci, a formação do grupo dirigente ou núcleo dirigente do PC era condição indispensável para que o partido pudesse cumprir seus objetivos políticos. A tal grupo caberia o papel de garantir a "formação de uma vanguarda proletária homogênea e ligada às massas" (Gramsci, 2004, v. 2, p. 351; v. 2, p. 129-402). Em outras palavras, para Gramsci, a formação do grupo dirigente constituía um ponto de partida fundamental para a construção do Partido Comunista e as características de tal grupo dirigente iriam definir o perfil da organização partidária em questão.

Cabe assinalar que a tática de "União Nacional" (Prestes, 2001) adotada pelos comunistas a partir de 1938, levou seus dirigentes e militantes a se inserirem de maneira espontânea e pouco crítica no movimento generalizado de repúdio às ameaças expansionistas e agressoras do nazifascismo europeu, secundado pelos integralistas, seus agentes internos em nosso país. Tal movimento empolgou setores muito amplos do espectro político brasileiro, incluindo numerosas camadas populares. A análise da atuação do PCB nesse período nos revela que, após os acontecimentos de novembro de 1935, os comunistas, profundamente golpeados e desarticulados, com grandes dificuldades para restabelecer os contatos com a Internacional Comunista (IC), não tiveram condições de manter uma postura ideologicamente independente (Prestes, 2001).

\footnotetext{
${ }^{2}$ Tribuna Popular, Rio de Janeiro, 27 jun. 1946, p. 1.
} 
A ausência, por parte do PCB, de uma justa compreensão da realidade do país contribuiu para que a direção do partido tivesse dificuldade de formular uma orientação política capaz de articular adequadamente a luta pela democracia no plano internacional, ou seja, o combate ao nazifascismo e aos seus agentes internos, com a luta pela democratização do país - contra o regime ditatorial do Estado Novo - e o empenho necessário para a construção das forças sociais e políticas capazes de levar adiante um projeto voltado para a emancipação econômica e social do país - um projeto que apontasse para uma efetiva transformação socialista, conforme constava dos documentos programáticos do PCB (Prestes, 2001).

Tais impasses na trajetória do movimento comunista no Brasil levaram à transformação do PCB num partido nacional-libertador, sob a influência das ideias nacionalistas presentes na sociedade brasileira. Um partido progressista em que, entretanto, o conflito entre trabalho e capital ficaria relegado a um segundo plano (Prestes, 2001).

A partir da Conferência da Mantiqueira, a orientação oficial do PCB, baseada na defesa da "União Nacional", não só deixava transparecer uma postura nacionalista, de defesa da soberania nacional diante do expansionismo nazifascista, mas também certo adesismo ao governo Vargas, o que se evidenciava nas páginas da revista Continental, que, na prática, se tornou o órgão oficioso do partido (Prestes, 2010, p. 51-52).

$\mathrm{Na}$ Conferência da Mantiqueira ficaram consagradas a hegemonia e a vitória das posições defendidas pela CNOP. Na ocasião foi nomeado um Comitê Central provisório, que se consolidaria com o apoio de Luiz Carlos Prestes, eleito secretário-geral in absentia, pela primeira vez desde seu ingresso no PCB. Segundo E. Carone, "é em agosto de 1945, na reunião legal do Comitê Nacional do PCB, denominado Pleno da Vitória, que os recalcitrantes irão aceitar a situação hegemônica do CNOP" (Carone, 1982, p. 3-4). Dessa forma, constituía-se o novo grupo dirigente do $\mathrm{PCB}$, que proclamava a liderança de Prestes e incluía entre seus membros nomes que figurariam à frente do PCB durante muitos anos, como Diógenes de Arruda Câmara, João Amazonas, Maurício Grabois, Pedro Pomar, Mário Alves, Amarílio Vasconcelos, Ivan Ramos Ribeiro, Giocondo Dias, Álvaro Ventura, etc.

Tal grupo dirigente sofreria algumas modificações no decorrer do tempo, mas foram seus elementos mais destacados que orientaram a reconstrução do PCB e o dotaram de um tipo de organização que correspondia aos objetivos políticos traçados na Conferência da Mantiqueira, o qual teria o caráter nacional-libertador da política 
partidária como marca registrada. As características desse novo grupo dirigente iriam definir o perfil da organização partidária que viria a existir daí por diante. O berço do novo $\mathrm{PCB}$, reconstruído após o desastre de 1940, seria a Conferência da Mantiqueira, e o seu novo perfil foi determinado pelo núcleo dirigente constituído nesse conclave.

$\mathrm{O} \mathrm{PCB}$, ao renascer dos violentos golpes desfechados pelo governo no início dos anos 1940, surgia como um partido marcado pela ideologia nacional-libertadora, com um grupo dirigente praticamente desconhecido, mas prestigiado pela presença de Luiz Carlos Prestes, cujo aval fora decisivo para a consolidação desse grupo, assim como da organização partidária. Tal núcleo dirigente empenhou-se na construção de uma estrutura partidária que correspondesse aos objetivos políticos traçados, ou seja, à defesa da soberania nacional, entendida como fruto do desenvolvimento de um capitalismo autônomo no Brasil (Prestes, 2010).

A análise do curto período de legalidade do PCB, nos anos 19451947, nos revela que, não obstante os esforços desenvolvidos pelos comunistas visando consolidar o processo de democratização no país e alcançar a tão almejada "União Nacional", o partido teve seu registro cancelado e os mandatos dos seus parlamentares cassados. "União Nacional" tornou-se uma quimera inatingível. Embora vitórias parciais tivessem sido conquistadas - algumas de grande importância -, a política levada adiante pelo PCB foi derrotada.

A diretriz de "União Nacional", durante o ano de 1945, contribuiu inquestionavelmente para um significativo avanço do processo de democratização do país. Já em 1946, com o início da chamada Guerra Fria, a tendência predominante na política nacional acabou sendo a de um crescente anticomunismo. Medidas repressoras, cada vez mais intensas, foram adotadas, por parte do governo E. G. Dutra, contra os comunistas e as forças democráticas e progressistas.

Os dirigentes do PCB não perceberam com clareza a profundidade de tal virada e a gravidade de suas consequências para o partido e para seus aliados. A hipotética "burguesia progressista", definida pelos comunistas como importante setor, com o qual seria possível contar na luta por "União Nacional", capitulara diante dos interesses do grande capital, expressos na Doutrina Truman (Vizentini, 2000, v. II, p. 195225; Munhoz, 2004, p. 273). Embora lutando com grande empenho e entusiasmo pelos objetivos traçados, os comunistas ficaram isolados, o que explica sua derrota política. 
Na realidade, mais uma vez, na história do PCB predominara a tendência nacional-libertadora e sua aposta no "papel progressista" de um setor da burguesia industrial, que seria capaz de aliar-se ao proletariado para alcançar um capitalismo autônomo no Brasil, livre do domínio do imperialismo, principalmente dos interesses dos capitais norte-americanos. Mais uma vez, o conflito de classes seria deixado de lado pelos comunistas, sendo privilegiada a luta nacional-libertadora.

\section{O PCB e o golpe de 1964}

O exame do período histórico que se estende até o golpe civilmilitar de março de 1964 nos mostra que, apesar das mudanças táticas havidas na política do PCB, a estratégia nacional-libertadora da revolução brasileira permaneceu intacta, marcando de maneira indelével a trajetória dos comunistas (Prestes, 1980, 2010, 2012). Uma concepção estratégica falsa, uma vez que inadequada à realidade que os comunistas pretendiam transformar. $\mathrm{O}$ capitalismo implantado no país surgira na época do domínio imperialista mundial exercido pelas potências centrais desse sistema, o que determinou sua posição subordinada, ou seja, a dependência a que ficou submetido. Não havia condições para a conquista de um desenvolvimento livre e independente do capitalismo brasileiro, meta que era perseguida pelos comunistas.

Em sua política de organização, consoante a concepção estratégica adotada pelo seu grupo dirigente criado ainda à época da Conferência da Mantiqueira, o PCB desenvolveu ingentes esforços no sentido da formação de uma estrutura partidária adequada à aplicação pela sua militância das diretrizes condizentes com tal estratégia. Foi construído um partido conforme tal orientação política, um partido empenhado numa aliança com uma suposta burguesia nacional progressista, para realizar reformas que pudessem garantir o advento de um desenvolvimento capitalista autônomo do país. O objetivo socialista era deixado para uma etapa posterior. Dessa maneira, não se investia na formação da força social e política, unificada por ideais comuns e voltada para a preparação das condições necessárias à revolução socialista.

$\mathrm{Na}$ realidade, tentava-se a criação de uma aliança de classes e setores sociais supostamente possuidores de interesses e reivindicações comuns na luta contra o imperialismo e o latifúndio e pela democracia. Mas, não se levava em conta algo que o conceito de bloco histórico, 
proposto por A. Gramsci - ou, em outras palavras, do sujeito-povo ${ }^{3}-$ pressupõe: o momento político dessa aliança. "Sua constituição está assentada em classes ou grupos concretos definidos pela sua situação na sociedade, mas as ideias cumprem um papel fundamental no que se refere à sua coesão" (Bignami, s.d., p. 27). No bloco histórico há "uma estrutura social - as classes e grupos sociais - que depende diretamente das relações entre as forças produtivas; mas também há uma superestrutura ideológica e política” (Bignami, s.d., p. 27). Gramsci escrevia nos Cadernos do cárcere que, segundo Marx, "uma persuasão popular tem, com frequência, a mesma energia de uma força material" (Gramsci, 2001, v. 1, p. 238). Tal afirmação, segundo o filósofo italiano,

conduz ao fortalecimento da concepção de 'bloco histórico', no qual precisamente, as forças materiais são o conteúdo e as ideologias são a forma, distinção entre forma e conteúdo puramente didática, já que as forças materiais não seriam historicamente concebíveis sem forma e as ideologias seriam fantasias individuais sem as forças materiais (Gramsci, 2001, v. 1, p. 238).

Os elementos citados da concepção gramsciana de bloco histórico permitem perceber o frequente empobrecimento de tal conceito no âmbito dos partidos comunistas, pois esse fenômeno marcou, de uma maneira geral, grande parte do movimento comunista mundial. Nas fileiras do PCB, semelhante postura teria como resultado a subestimação pelo trabalho ideológico de formação teórica e política não só dos seus quadros, como também de lideranças populares. A incompreensão da necessidade de criar um bloco histórico contra-hegemônico, capaz de conduzir o processo revolucionário à vitória, condicionou o desarmamento ideológico e político dos comunistas diante do bloco histórico dominante e a inevitável capitulação frente ao reformismo burguês (Prestes, 2010a).

Durante o período histórico que antecedeu a deposição do presidente Goulart, a atividade prática da militância do PCB evidenciou as limitações provenientes da incompreensão citada. A atuação dos comunistas no Sindicato dos Metalúrgicos do Rio de Janeiro, no período 1945/1964, é nesse sentido exemplar. Conforme é mostrado por Santana (Santana, 2012), diferentemente do que sempre se afirmou, "no plano

\footnotetext{
${ }^{3}$ Sujeito-povo: categoria empregada por alguns intelectuais latino-americanos, relacionada com o conceito gramsciano de bloco histórico, ou seja, sujeito-povo expressa não só a soma numérica de diversos setores sociais, mas também é portador de novos valores culturais e constitui uma alternativa de poder (cf., por exemplo, Bignami, 2009, p. 23, 26, 28 e 107).
} 
organizacional os comunistas vão ser incansáveis na atuação nos locais de trabalho e na constituição de comissões sindicais de empresa, alterando, na prática, a perspectiva de ação dos sindicatos" (Santana, 2012, p. 237; grifos meus). Os comunistas chegaram, em muitos momentos, a ter importante participação e indiscutível liderança nas lutas dos trabalhadores nas fábricas, conseguindo alcançar sucesso na organização dos trabalhadores. (Santana, 2012) Entretanto, quais eram as propostas em torno das quais se dava esse trabalho de organização?

A pesquisa da atuação da militância comunista no Sindicato dos Metalúrgicos do Rio de Janeiro revela que a orientação política do PCB, marcada pela concepção estratégica nacional-libertadora, levou a que, no âmbito do referido setor metalúrgico, os comunistas priorizassem a aliança com o PTB (Partido Trabalhista Brasileiro), fundado por Vargas em 1945. Na prática, tratava-se da aliança com Benedito Cerqueira, importante liderança desse partido no Sindicato dos Metalúrgicos do Rio de Janeiro (Santana, 2012). "O crescimento de poder de fogo dos comunistas no interior da categoria e da direção sindical, que atingiu o maior índice da história, acabou sendo diluído devido à política de unidade que, contraditoriamente, o havia possibilitado" (Santana, 2012 , p. 213). Em nome da unidade com os trabalhistas, os militantes comunistas foram levados a seguir uma orientação reformista, de caráter nacionalista burguês. Tanto as diretrizes do PCB quanto as que eram adotadas pelo PTB tinham a marca da ideologia do nacionaldesenvolvimentismo, corrente, que, a partir dos anos 1950, teve ampla aceitação, por parte de expressivos setores do pensamento brasileiro, inclusive, tacitamente, por parte dos comunistas. (Prestes, 2010, p. 55-59)

A ausência de uma efetiva autonomia política eorganizacional - resultante de uma concepção estratégica inadequada às condições brasileiras - condicionou a atuação dos comunistas, impedindo-os de avançar no sentido da formação do bloco histórico - ou do sujeitopovo - ou, em outras palavras, das forças sociais e políticas capazes de impulsionar a realização das Reformas de Base, colocadas em pauta naqueles anos e, nesse processo, preparar as condições para avançar rumo às transformações de caráter revolucionário, que apontassem para a conquista do poder político e a transição para o socialismo.

A análise do desenrolar dos acontecimentos que tiveram como desfecho o golpe civil-militar de 31/3/1964 e a deposição do governo

${ }^{4} \mathrm{O}$ golpe teve início no dia 31/3, embora a deposição de João Goulart só tenha ocorrido na noite de $1^{\circ}$ para 2 de abril de 1964 . 
de João Goulart justifica plenamente a opinião de Waldir Pires, então consultor-geral da República, emitida 20 anos mais tarde: "Havia muito mais a retórica dos discursos do que propriamente uma ação organizada para preservar o processo democrático" (Moraes, 1989, p. 198).

As concepções nacional-libertadoras, presentes tanto na estratégia política do PCB quanto em grande parte do discurso das forças nacionalistas e de esquerda, sob a influência dominante da ideologia nacional-desenvolvimentista, alimentaram as ilusões num hipotético antiimperialismo de uma suposta burguesia nacional ${ }^{5}$ e na possibilidade de sob a pressão das manifestações das forças nacionalistas e democráticas e, em particular, do movimento sindical - levar o presidente João Goulart a realizar reforma ministerial que permitisse o estabelecimento de um governo nacionalista e democrático e a implementação das Reformas de Base. Cogitava-se ainda de uma reforma constitucional, mesmo que para tal fosse necessário passar por cima do Congresso Nacional.

As consequências práticas da presença de uma concepção reformista da revolução por etapas, ou seja, da ideia de alcançar um governo nacionalista e democrático dentro dos marcos do regime capitalista - etapa que seria necessária para prosseguir na luta pela realização da revolução socialista - pouco diferiam das consequências oriundas do voluntarismo, da impaciência e da pressa dos adeptos das concepções esquerdistas, típicas dos setores pequeno-burgueses. Ambas as concepções - a reformista de direita e a do radicalismo esquerdista dificultaram a organização e a conscientização das massas trabalhadoras, premissa necessária para a conquista do poder e a realização das reformas necessárias para iniciar outro tipo de desenvolvimento, livre e independente e voltado, portanto, para uma transformação de caráter socialista, mesmo que não fosse de imediato.

Uma abordagem autocrítica da estratégia dos processos revolucionários em duas etapas, adotada pelos comunistas latinoamericanos, foi apresentada, com indiscutível clarividência, pelo líder revolucionário e dirigente do Partido Comunista Salvadorenho Schafik Handal:

[...] Não pode haver revolução sem resolver a fundo o problema do poder. [...] Nosso partido, e me parece que muitos outros partidos comunistas da América Latina, temos trabalhado durante decênios com a idéia de duas revoluções [...]. Reagimos tantas e tantas vezes contra a colocação esquerdista da luta pela implantação direta,

\footnotetext{
${ }_{5}$ As ilusões no "dispositivo militar" de Jango faziam parte de tal concepção nacional-libertadora.
} 
sem estágios, do socialismo e chegamos a nos convencer de que a revolução democrática não é necessariamente uma tarefa a ser organizada e promovida principalmente por nós. Que poderíamos nos limitar e nos conformarmos em ser força de apoio e assegurar a amplitude do leque das forças democráticas participante. Assim, a revolução democrática anti-imperialista se nos apresentava como uma 'via de aproximação', que pode alcançar-se deixando na dianteira da ação setores 'progressistas', 'anti-imperialistas', das camadas médias (da intelectualidade, dos militares, etc.) e até da burguesia. [...] O que surge de tal conduta não é nem pode ser o partido da revolução mas sim o partido das reformas. [...] (Handal; grifos meus).

A seguir Handal escrevia:

Se aceitamos que a revolução democrática e anti-imperialista é parte inseparável da revolução socialista, não se pode realizar a revolução tomando pacificamente o poder por partes, será indispensável sob uma ou outra foram, desmantelar a máquina estatal dos capitalistas e seus amos imperialistas, erigir um novo poder e um novo estado (Handal).

Embora Jango tivesse avançado no intento de realizar as reformas - e isso ficou patente no comício de 13 de março de 1964 -, o golpe militar, com amplo apoio civil e participação decisiva do governo dos EUA (Tavares, 2014), foi arquitetado para garantir o sucesso do seu desfecho. Jango ficara isolado, sem contar com bases organizadas que o sustentassem, pois nas próprias Forças Armadas a correlação de forças deixara de lhe ser favorável, diferentemente do que tivera lugar quando da renúncia de Jânio Quadros, revelando que setores ponderáveis dos militares nacionalistas haviam sido influenciados pela intensa campanha anticomunista desencadeada pelos golpistas. A ameaça de Jango romper com a legalidade constitucional ajudou a desarticular seu "dispositivo militar".

Cabe registrar que, para o isolamento do presidente João Goulart, tiveram influência as pressões sobre ele exercidas de setores radicalizados, portadores de uma retórica esquerdizante, sem o respaldo, contudo, de um movimento popular capaz de lhe oferecer sustentação real. Logo após o comício de 13 de março, Darcy Ribeiro, Chefe da Casa Civil, transmitiu à direção do $\mathrm{PCB}$ cópia de documento intitulado Projeto Brasil, de caráter bastante radical, que Jango não desejava encaminhar ao Congresso sem o apoio dos comunistas. Luiz Carlos 
Prestes, contrário ao documento ${ }^{6}$, conta que o assunto foi discutido na Comissão Executiva do Comitê Central do PCB, que o aprovou, considerando que deveria ser ainda mais radical. Esta era a posição de dirigentes como Carlos Marighella e Mário Alves. Darcy Ribeiro teria ficado radiante com o apoio do PCB. Na opinião de Prestes, sua postura era evidentemente esquerdista. O Projeto Brasil, encaminhado ao Congresso Nacional, não chegou a ser discutido ${ }^{7}$.

Diante do isolamento de Goulart e das forças nacionalistas e democráticas, seria suicídio para o PCB tentar reagir ao golpe através da luta armada. Naquele momento, a única alternativa viável foi o recuo para a clandestinidade, tentando manter, na medida do possível, a estrutura partidária. $\mathrm{Na}$ ausência de condições reais para a vitória de um movimento revolucionário, a história mundial da luta de classes ensina que a solução correta é recuar. Em outubro de 1923, a direção do Partido Comunista Alemão, ao tomar conhecimento de que a maioria dos delegados operários, que eram socialistas de esquerda, rejeitara a proposta comunista de deflagrar insurreição armada na Alemanha, agiu com acerto suspendendo a decisão adotada anteriormente. Em Hamburgo, onde a determinação de recuar não chegou a tempo, durante três dias travou-se uma encarniçada luta contra a polícia e o exército, sem que as massas proletárias da cidade apoiassem ativamente os insurretos, demonstrando que o proletariado alemão, naquele momento, não estava disposto a pegar em armas (Claudin, 1970, p. 106-107).

A trágica experiência das organizações de esquerda, que recorreram a diferentes formas de luta armada no combate à ditadura, demonstrou na prática que inexistiam condições para tal no Brasil de então. Durante o período de relativas liberdades anterior ao golpe reacionário de março de 1964, as esquerdas haviam subestimado tanto a necessidade de elaboração programática quanto o trabalho de organização e de conscientização das forças populares para levar adiante o processo revolucionário no país. Com o estabelecimento da ditadura, o esforço de organização e conscientização das massas ficaria muito mais demorado e difícil.

\footnotetext{
${ }^{6}$ L. C. Prestes, naquele período, ainda apoiava a estratégia nacional-libertadora do PCB, da qual iria afastar-se posteriormente. (Prestes, 2012)

${ }^{7}$ LCP (entrevistas concedidas por Luiz Carlos Prestes a Anita Leocadia Prestes e Marly de Almeida Gomes Vianna, gravadas em fita magnética e transcritas; RJ, 1981-83). LCP, fita $\mathrm{n}^{\circ} \mathrm{XX}$.
} 


\section{O PCB diante da derrota de abril de 1964}

Com a derrota das forças nacionalistas e democráticas em abril de 1964, as divergências existentes nos meios de esquerda e, em particular, na direção do PCB iriam agravar-se consideravelmente. No Comitê Central do PCB, formou-se um agrupamento composto por Carlos Marighella, Mário Alves, Joaquim Câmara Ferreira, Jover Telles, Apolônio de Carvalho e Jacob Gorender, o qual, desde 1962, passara a defender a luta contra a "conciliação" de Jango, adotando posições cada vez mais "esquerdizantes" e de questionamento da orientação política aprovada no V Congresso do PCB, realizado em 1960 (Carone, 1984, p. 8) . $^{8}$

Carlos Marighella, em documento de dezembro de 1966, reconhecia que "nossas discordâncias não são de agora", datando pelo menos de 1962, e acrescentava: “A saída no Brasil (...) só pode ser a luta armada, o caminho revolucionário, a preparação da insurreição armada do povo, com todas as conseqüências e implicações que daí resultam" (Marighella, 1979, p. 91 e 93).

Mário Alves e Marighella, ainda antes do golpe, haviam aderido ao "modelo cubano", ou seja, entusiasmados com a Revolução Cubana, desejavam transplantar essa experiência para o Brasil. Mário Alves foi o primeiro membro da direção do $\mathrm{PCB}$ a visitar oficialmente Cuba, em 1961, a convite das Ligas Camponesas dirigidas por Fancisco Julião, cujo "trânsito com Fidel Castro era livre" (Falcón, 2008, p. 216-217). Anos mais tarde, Prestes recordaria que Mário Alves, após viagem a Cuba, convencera-se de que no Brasil deveria ser desencadeada a luta armada. Lembraria também que a influência do discurso radical de Julião e do exemplo cubano de luta de guerrilhas era muito forte em nosso meio (LCP, fita $\mathrm{n}^{\mathrm{o}} \mathrm{XIX}$ ).

Em 1963, Prestes teve um encontro em São Paulo com o primeirosecretário da embaixada cubana no Brasil: "ele queria fazer guerrilhas aqui no Brasil. E o Marighella se deixou levar porque mantinha íntimas ligações com a Embaixada de Cuba". Prestes considerava que "a concepção de luta armada se desenvolveu na América Latina em peso, porque dois partidos comunistas que estavam no poder apoiavam isso - o PC chinês e o PC cubano" (Moraes, 1997, p. 195-196). Afirmava ainda que "o Marighella estava muito ligado à Embaixada cubana. (...) E também Mário Alves, chefe da seção de educação, o Jover Telles e

\footnotetext{
${ }^{8}$ As divergências na Comissão Executiva do CC do PCB podem ser acompanhadas ao consultar as anotações de Prestes em suas cadernetas apreendidas pela polícia por ocasião do golpe de 1964, "Cadernetas de Prestes", 2DVDs. Arquivo Público do Estado do RJ (APERJ).
} 
o Apolônio de Carvalho. Já estavam fazendo um trabalho de educação do partido contra a linha do próprio partido!" (Moraes, 1989, p. 179).

Com a vitória dos golpistas e a repressão que imediatamente se desencadeou contra as forças democráticas e de esquerda, a situação do PCB tornou-se particularmente difícil. O partido não esperava o golpe e não se havia preparado para enfrentá-lo. Mesmo na Comissão executiva do Comitê Central, em que predominavam as posições esquerdistas, não haviam sido tomadas medidas práticas para fazer frente à repressão. A maioria esquerdista acreditava que a pressão exercida sobre Jango o faria avançar no caminho da superação da conciliação e da realização das reformas, até mesmo ultrapassando os limites da legalidade constitucional. Os adeptos das posições esquerdistas coincidiam com os adeptos das concepções reformistas ao confiarem, tanto uns quanto os outros, no "esquema militar" de Goulart, abdicando na prática do trabalho de organização, conscientização e mobilização popular.

Frente ao golpe, era necessário que o partido se pronunciasse. Ainda em abril, Prestes, em nome dos comunistas brasileiros, divulgava o manifesto intitulado "A derrota dos golpistas abrirá caminho à revolução brasileira". No documento era denunciado o caráter reacionário do golpe, que levara à implantação de uma "ditadura das forças retrógradas, dos agentes do imperialismo e do latifúndio". Afirmava-se que "o dever supremo de todos os brasileiros nesta hora é a defesa intransigente das liberdades democráticas contra os atentados da reação". Fazia-se um apelo à luta pelas "reivindicações imediatas dos trabalhadores, em defesa da soberania nacional, pelas reformas de base indispensáveis ao progresso do país", assim como à unidade de todos os "patriotas e democratas", de "todas as correntes políticas que não aceitam a ditadura, num poderoso movimento de massas capaz de conduzir à derrota dos golpistas e à conquista de um governo nacionalista e democrático, representante das forças que lutam pela liberdade, a independência e o progresso de nossa Pátria". Prestes referia-se também à necessidade de comunistas contribuírem para a organização popular, "para resistir e lutar contra a ditadura por todos os meios, desde os protestos mais elementares até os atos públicos, as manifestações de rua e a autodefesa das massas". O Manifesto encerrava-se com o apelo à "unidade, organização e luta de massas para derrotar a ditadura reacionária"9.

\footnotetext{
9 PRESTES, Luiz Carlos, "A derrota dos golpistas abrirá caminho à revolução brasileira" (Manifesto), documento datilografado (tradução para o espanhol), 4 p., abr. 1964; grifos meus. Fundo Roberto Morena, Cedem/Unesp.
} 
Em maio de 1964, reuniu-se no Rio de Janeiro a Comissão Executiva do PCB com o objetivo de realizar uma primeira apreciação da nova situação criada no país. Participaram da reunião apenas alguns de seus membros (Marighella, Mário Alves, Joaquim Câmara Ferreira, Jover Telles, Giocondo Dias e Orlando Bonfim Jr.), pois os demais, inclusive Prestes, dadas as condições de rigorosa clandestinidade, não puderam comparecer (Falcão, 1993, p. 243; Falcón, 2008, p. 218; Gorender, 1987, p. 87).

Os esquerdistas estavam em maioria, o que se refletiu no documento então aprovado, intitulado "Esquema para discussão"10. Sua tônica, diferentemente do Manifesto lançado anteriormente por Prestes, era a proposta da "derrubada da ditadura". Partia-se, no documento, de uma análise segundo a qual os erros cometidos pelo partido teriam sido de "direita". Reafirmava-se que "as reformas de base exigiam a ruptura da política de conciliação entre Goulart e as forças reacionárias que participavam do governo e detinham a maioria do Congresso". Continuava-se a insistir no acerto da posição adotada desde 1962 pela direção partidária de combate prioritário à política de conciliação de Jango. No documento, eram criticadas as ilusões de classe existentes no partido, destacando-se a "confiança excessiva na disposição de luta da burguesia nacional", a confiança no "dispositivo militar" de Goulart e o despreparo do partido para "uma luta dura". Dizia-se: "Absolutizamos a possibilidade do caminho pacífico e não nos preparamos para enfrentar o emprego da luta armada pela reação".

Ao mesmo tempo, havia uma aposta otimista na reação popular contra a ditadura: "São imensas as forças que se levantarão contra a ditadura reacionária". É interessante assinalar que no "Esquema para discussão" reafirmava-se a tese de que "o objetivo tático central de nossa luta continua sendo a conquista de um governo nacionalista e democrático, isto é, de um governo que inicie as reformas necessárias à libertação e ao progresso do Brasil". Diferentemente dos documentos anteriores do PCB, dizia-se que "para atingir esse objetivo é necessária a derrubada da ditadura reacionária que se instaurou no país". Destacava-se ainda a necessidade de o partido preparar-se para a "possibilidade de ter de enfrentar a reação no terreno da luta armada" e ter em vista, "sobretudo no campo, a possibilidade de choques armados com a reação" (grifos meus). Ao final do documento, afirmava-se: "A derrubada da ditadura

10"Esquema para discussão", documento mimeografado, 6 p., s.d. Fundo Roberto Morena, Cedem/Unesp. 
golpista abrirá caminho para a vitória da revolução brasileira, para a libertação final do Brasil do domínio do imperialismo, do latifúndio e da reação" (id.).

Podemos perceber no texto desse documento que, mais uma vez na história do PCB, tentava-se uma guinada tática, com o abandono do caminho eleitoral e pacífico e a adoção de meios armados para derrubar a ditadura, sendo mantida, entretanto, a estratégia da etapa nacional e democrática da revolução (Prestes, 1980).

Nas condições de rigorosa clandestinidade, devido à violenta repressão desencadeada pela ditadura contra os comunistas, o Comitê Central do PCB reuniu-se, pela primeira vez após o golpe de 1964, em maio de 1965, em São Paulo. Nessa reunião, a maioria do Comitê Central rejeitou o "Esquema para a discussão" elaborado um ano antes e que expressava as concepções da posteriormente denominada "tendência revolucionária" ou "corrente revolucionária" (Mário Alves, Carlos Marighella, Joaquim Câmara Ferreira, Jacob Gorender, Jover Telles, Apolônio de Carvalho e Miguel Batista). Na "Resolução Política"11, afirmava-se que, com o golpe de $1^{\circ}$ de abril, "constituiu-se uma ditadura militar, reacionária e entreguista, sob o governo de fato exercido por um grupo de generais a serviço da embaixada dos Estados Unidos" (RP, p. 4). Destacava-se a submissão do país ao Fundo Monetário Internacional (FMI) e considerava-se que "a política econômico-financeira da ditadura também atinge os interesses da burguesia nacional, cada vez mais ameaçada pela concorrência imperialista". Dizia-se que se acentuava a "premência das reformas de estrutura" (RP, p. 5).

O Comitê Central do PCB afirmava em sua "Resolução Política":

O objetivo tático imediato [...] é isolar e derrotar a ditadura e conquistar um governo amplamente representativo das forças antiditatoriais, que assegure as liberdades para o povo e garanta a retomada do processo democrático interrompido pelo golpe reacionário e entreguista. Os comunistas se empenham no sentido de que tal governo seja o mais avançado possível, mas compreendem que sua composição não poderá deixar de refletir o nível alcançado pelo movimento de massas e a correlação de forças existente no momento em que se constituir (RP, p. 7-8).

A seguir, no mesmo documento, dizia-se que "o êxito dessa luta dependerá fundamentalmente da unidade de ação de todas as forças,

11 "Resolução Política do Comitê Central do Partido Comunista Brasileiro" - RP (maio 1965), folheto impresso, 16 p.; Carone (1982, p. 15-27). 
correntes e setores políticos que se opõem à ditadura", postulando a formação de uma "ampla frente de resistência, oposição e combate à ditadura" e considerando que o elo principal dessa luta deveria ser a defesa das liberdades democráticas. Nessas circunstâncias, "a luta por eleições livres e nossa participação ativa em todas as campanhas eleitorais se revestem de enorme importância para fazer avançar a luta pelas liberdades democráticas e pela conquista de um novo governo" (id., p. 8). Reafirmava-se a perspectiva da conquista de um governo nacionalista e democrático, "capaz de iniciar e levar adiante as reformas de estrutura, aproximando nosso povo dos objetivos da atual etapa da revolução brasileira" (RP, p. 12).

A análise da "Resolução Política" confirma que, em termos de perspectivas táticas e estratégicas, a posição vencedora no Comitê Central do PCB fora a da fidelidade às teses aprovadas no V Congresso do partido. No final desse documento, tentava-se analisar autocriticamente a atuação do partido diante do governo Jango e frente ao golpe de abril. Reconhecia-se que "fomos colhidos de surpresa e despreparados", que a direção do partido havia confiado no "dispositivo militar de Goulart" e que houvera "reboquismo em relação ao setor da burguesia nacional que estava no poder". Após reafirmar a justeza da linha política aprovada no V Congresso, que "permitiu ao Partido estreitar suas ligações com as massas e participar ativamente da vida política, contribuindo de tal maneira para o avanço do processo revolucionário", dizia-se que, "desde a posse de Goulart [...], preocupados em lutar contra a conciliação, começamos a nos afastar da linha política. Esse processo culminou nos últimos meses do governo Goulart, quando de fato abandonamos a luta pela justa aplicação da linha" (RP, p. 13).

Ao fazer uma apreciação autocrítica do desempenho partidário, afirmava-se na "Resolução Política" que fora justo combater com firmeza a política de conciliação, mas a forma de fazê-lo teria sido inadequada. A seguir reconhecia-se que

nossa atividade em relação ao governo de Goulart era orientada, na prática, como se sua política fosse quase inteiramente negativa. Desprezávamos seus aspectos positivos de grande importância [...] Atuávamos considerando a luta contra a conciliação como a forma concreta pela qual devia ser combatido, nas condições existentes, o maior inimigo de nosso povo - o imperialismo norte-americano. Semelhante posição política só poderia levar ao desvio do golpe principal, transferindo-o para a burguesia nacional (RP., p. 13-14). 
No documento do Comitê Central, fazia-se uma avaliação crítica da Nota da Comissão Executiva de 27 de março de 1964, na qual,

ao lado da reivindicação da formação imediata de um novo governo, que 'pusesse termo à política de conciliação', transferíamos o centro de ataque para o Parlamento, exigindo a reforma constitucional e ameaçando o Congresso [...] Permitíamos, dessa forma, que a defesa da legalidade fosse utilizada pelas forças da reação para enganar amplos setores da população e arrastá-los ao golpe reacionário (RP., p. 15).

\section{Finalmente, considerava-se na "Resolução Política" que}

na raiz de nossos erros está uma falsa concepção, de fundo pequenoburguês e golpista, da revolução brasileira [...] É uma concepção que admite a revolução não como um fenômeno de massas, mas como resultado da ação das cúpulas, ou, no melhor dos casos, do Partido. Ela imprime à nossa atividade um sentido imediatista, de pressa pequeno-burguesa, desviando-nos da perspectiva de uma luta persistente e continuada pelos nossos objetivos táticos e estratégicos, através do processo de acumulação de forças e da conquista da hegemonia pelo proletariado (RP., p. 15).

Tais conclusões, aprovadas pela maioria do Comitê Central em maio de 1965, não seriam aceitas pela "corrente revolucionária", defensora da derrubada da ditadura através da luta armada. Seus adeptos passaram a repudiá-la abertamente, desenvolvendo atividades fracionistas ${ }^{12}$ nas organizações partidárias: Marighella e Câmara Ferreira em São Paulo; Mário Alves em Minas Gerais; Telles na Guanabara; Apolônio de Carvalho e Miguel Batista no estado do Rio de Janeiro; Jacob Gorender no Rio Grande do Sul (Carvalho, 1997, p. 196).

O quadro político nacional era de "fechamento" crescente do regime, que se esforçava, contudo, em manter uma aparência de normalidade das instituições representativas, com a realização de pleitos eleitorais e o funcionamento do Parlamento e, até mesmo, com o embuste da escolha do presidente da República pelo Congresso Nacional, o que acabaria perdurando durante os 21 anos do regime ditatorial.

\footnotetext{
${ }^{12}$ Atividade fracionista: atividade nas organizações do partido comunista contrária às resoluções adotadas pela direção do partido e condenada pelo movimento comunista internacional, cujo princípio de organização sempre foi o centralismo democrático (democracia na tomada das decisões e centralismo em sua aplicação).
} 
Em vez de um rápido desgaste da ditadura, previsto por muitos militantes e dirigentes das esquerdas, observava-se a tendência à sua consolidação e à permanência por longo período. Tendo como pano de fundo tal panorama político, a luta interna nas fileiras do PCB iria agravar-se.

A partir desse momento, seriam criadas diversas organizações empenhadas em levar adiante a luta armada contra a ditadura, todas desbaratadas com violência pelos governos militares. À frente de muitas dessas organizações estavam antigos dirigentes do PCB (Carlos Marighella, Mário Alves, Apolônio de Carvalho, etc.), adeptos da "corrente revolucionária", expulsos do partido pela comprovação de sua intensa atividade fracionista.

O golpe civil-militar de 1964 levou à derrota das esquerdas e essa derrota teve como um de seus principais resultados o esfacelamento do PCB, que a partir de então não conseguiu recuperar seu anterior prestígio e influência na sociedade brasileira; também foram aniquiladas todas as organizações da chamada ultra-esquerda, que recorreram à luta armada contra a ditadura.

\section{Os ensinamentos da derrota de 1964}

A derrota das esquerdas em 1964 traz ensinamentos que continuam válidos na atualidade: o caminho da revolução, cuja estratégia hoje deve ser socialista, passa pela construção do bloco histórico contrahegemônico, que represente a unidade de amplas forças sociais e políticas em torno de um projeto revolucionário condizente com a realidade atual do País. Tal projeto deverá resultar das lutas dos trabalhadores e da sua organização para alcançar objetivos parciais que possam contribuir para acumulação de forças e a criação de condições - inclusive a formação de partidos políticos revolucionários - para a conquista do poder político, objetivo sem o qual o processo revolucionário ficaria inconcluso e sujeito a novas derrotas.

\section{Referências}

BIGNAMI, Ariel. El pensamiento de Gramsci: una introduccion. 2. ed. Buenos Aires: Editorial El Folleto, s.d.

BIGNAMI, Ariel. Intelectuales \& revolución o el tigre azul. Buenos Aires: Acercándonos Ediciones, 2009.

CARONE, Edgard. O P.C.B. (1964-1982). São Paulo: Difel, 1982. Vol. 3.

CARONE, Edgard. Movimento operário no Brasil (1964-1984). São Paulo: Difel, 1984. 
CARVALHO, Apolônio de. Vale a pena sonhar. Rio de Janeiro: Rocco, 1997.

CLAUDIN, Fernando. La crisis del movimiento comunista. França: Ediciones Ruedo Ibérico, 1970. Tomo 1.

FALCÃO, João. Giocondo Dias, a vida de um revolucionário (meio século de história política do Brasil). Rio de Janeiro: Agir, 1993.

FALCÓN, Gustavo. Do reformismo à luta armada: a trajetória política de Mário Alves (1923-1970). Salvador: EDUFSA-Versal Editores, 2008.

GORENDER, Jacob. Combate nas trevas; a esquerda brasileira: das ilusões partidas à luta armada. São Paulo: Ática, 1987.

GRAMSCI, Antônio. Cadernos do cárcere. 2. ed. Rio de Janeiro: Civilização Brasileira, 2001. v. 1 .

GRAMSCI, Antônio. Escritos politicos. Rio de Janeiro: Civilização Brasileira, 2004. 2 v.

HANDAL, Schafik. O poder, o caráter, a vida da revolução e a unidade da esquerda, FMNL, início da década de 1980, 15 páginas, <http://pcbjuizdefora.blogspot.com. br/2011/01/o-poder-o-carater-via-da-revolucao-e.html>.

MARIGHELLA, Carlos. Escritos de Carlos Marighella. São Paulo: Livramento, 1979.

MORAES, Denis. A Esquerda e o golpe de 64: vinte e cinco anos depois, as forças populares repensam seus mitos, sonhos e ilusões. Rio de Janeiro: Espaço e Tempo, 1989.

MORAES, Denis (Org.). Prestes com a palavra: uma seleção das principais entrevistas do líder comunista. Campo Grande: Letra Livre, 1997.

MUNHOZ, Sidnei. Guerra Fria: um debate interpretativo. In: DA SILVA, Francisco Carlos Teixeira (Org.). O século sombrio: guerras e revoluções do século XX. Rio de Janeiro: Elsevier, 2004. p. 239-259.

PRESTES, Anita Leocadia. A que herança devem os comunistas renunciar? Oitenta, Porto Alegre: LP\&M, n. 4, p. 197-223, 1980.

PRESTES, Anita Leocadia. Da insurreição armada (1935) à “União Nacional” (19381945): a virada tática na política do PCB. São Paulo: Paz e Terra, 2001.

PRESTES, Anita Leocadia. Os comunistas brasileiros (1945-1956/1958): Luiz Carlos Prestes e a política do PCB. São Paulo: Brasiliense, 2010.

PRESTES, Anita Leocadia. Antônio Gramsci e o ofício do historiador comprometido com as lutas populares. Revista de História Comparada, v. 4, n. 3, p. 6-18, dez. 2010a, $<$ http://www.hcomparada.historia.ufrj.br/revistahc/revistahc.htm>.

PRESTES, Anita Leocadia. Luiz Carlos Prestes: o combate por um partido revolucionário (1958-1990). São Paulo: Expressão Popular, 2012.

PRESTES, Anita Leocadia. O PCB e o golpe civil-militar de 1964: porque as esquerdas foram derrotadas em 1964? Polo Comunista Luiz Carlos Prestes. Disponível em: $<$ http:// www.cclcp.org/index.php/inicio-pclcp/formacao>. Acesso em: 6 nov. 2013,

SANTANA, Marco Aurélio. Bravos companheiros: comunistas e metalúrgicos no Rio de Janeiro (1945/1964). Rio de Janeiro: 7 Letras, 2012,

TAVARES, Flávio. 1964: o golpe. Porto Alegre: L\&PM, 2014.

VIZENTINI, Paulo G. Fagundes. A Guerra Fria. In: REIS FILHO, Daniel Aarão et al. (Org.). O século XX. Rio de Janeiro: Civilização Brasileira: 2000. v. 2. p. 195-225. 